\title{
Modification of Fatty Acid Profiles of Rapeseed (Brassica napus L.) Oil for Using as Food, Industrial Feed-Stock and Biodiesel
}

\author{
Ujjal Kumar Nath ${ }^{1}$, Hoy-Taek Kim ${ }^{1}$, Khadiza Khatun ${ }^{2}$, Jong-In Park ${ }^{1}$, Kwon-Kyoo Kang ${ }^{3}$, Ill-Sup Nou ${ }^{1}$ * \\ ${ }^{1}$ Department of Horticulture, Sunchon National University, Suncheon 57922, Korea \\ ${ }^{2}$ Department of Agricultural Industry Economy and Education, Sunchon National University, Suncheon 57922, Korea \\ ${ }^{3}$ Department of Horticulture, Hankyong National University, Anseong 17579, Korea
}

\begin{abstract}
Rapeseed is a member of family Brassicaceae, cultivated as oil crop. Rapeseed oil is being utilized from early civilization, but its popularity being declined from the mid-nineteenth century due to presence of erucic acid (C22:1) and glucosinolates. Thereby, several attempts have been made to develop cultivars free from those toxins. In the past 20 years, breeders got success in developing '00'- quality rapeseed, known as 'Canola'. The target mutagenesis of fae-1 and fae-2 of Brassica napus ensured such success. Thereafter, 'canola' regains its market as a healthy vegetable oil. Moreover, high oleic acid rapeseed lines, with $86 \%$ oleic acid, have been developed by using chemical mutagenesis of $F A D 2$ alleles responsible for desaturation of oleic acid (C18:1) to linoleic acid (C18:2). Recently, high erucic acid rapeseed oil regained interest for biodegradable plastic, cosmetic, emollient industries and for biodiesel. Therefore, breeding approaches have been pursued; unfortunately, that were failed to reach erucic acid level beyond $50 \%$ in seed-oil. Rapeseed genotypes over-expressed with $L d-L P A A T$ separately and $L d-L P A A T-F A E$ chimaric construct together were tried but failed to reach the erucic acid content more than $60 \%$. Thereof, combined effort of conventional breeding and transgenic approaches are brought together to overcome three hypothesized bottlenecks; reviewed in this article, which restricted erucic acid level near to $60 \%$. Finally, rapeseed genotypes with $78 \%$ erucic acid were developed successfully. This material is now available in Germany for using in emollient industries and for biodiesel. Therefore, this article is reviewed on the current status and future outlook for modification of fatty acid profiles of rapeseed oil for its end-use as food, industrial feed-stock and biodiesel.
\end{abstract}

Keywords Brassica napus, Fatty acid composition, Food, Biodiesel

\section{INTRODUCTION}

Brassica is the genus with more than 51 genera in the family Brassicaceae, it is economically important genus containing 37 different species (Gómez-Campo 1980). Brassica genus included many crop species provided edible parts and seeds. Brassica are of great importance as vegetables throughout the world. The main species are Brassica oleracea and B. rapa included cabbages, brussel sprouts, cauliflower, broccoli, Kimchi cabbage, Pakchoi etc. (Rakow 2004). Besides, the vegetable crops, some species of this genus are equally important as source of vegetable oils. The oleiferous Brassica represented by rapeseed and mustard play an important role for vegetable oil production worldwide. Oil plays an important role in our daily diet. From nutritional point of view, fats and oils in our daily life are mostly needed for calories and fat soluble vitamins absorbent. At present, rapeseed is the second most important oilseed in the world, after soybean and palm; and is used for both nutritional and industrial purposes (FAO 2014).

Brassica oilseed production has increased over the last 50 years (FAO 2014). The largest acreage of Brassica oilseeds is found in India, followed by China and Canada. Highest seed yields are contributed from Europe (France, Germany and the UK) with average yields of about 3.0 tonnes/ha, more than twice the seed yields obtained in Canada and Australia (Rakow 2004). This is due to the fact that, in Europe, the winter annual forms of B. napus are grown under favourable growing conditions, which are

Received May 17, 2016; Revised May 25, 2016; Accepted May 26, 2016; Published May 31, 2016

*Comesponding author Ill-Sup Nou, nis@sunchon.ac.kr, Tel: +82-61-750-3249, Fax: +82-61-750-3208 
comparatively more productive than spring $B$. napus forms. Canada and Australia are major rapeseed-exporting countries while Japan and China are major importers (Kimber and McGregor 1995). More than half of the rapeseed oil marketed internationally is refined in the European Union (EU). The production in India, China and other countries is locally consumed.

The past fifty years have seen significant growth in rapeseed production due to the introduction of food rapeseed (canola), low in erucic acid (22:1; cis-13 docosenoic acid) and glucosinolates (Lühs and Friedt 1994; Przybylski and Mag 2002). Presently, fatty acids profile of rapeseed oil has been modified according to the market prospects with health benefits. However, there are several arguments about the rapeseed oil-health relationship. The major ones were point-outs originally by Trautwein and Erbersdobler (1998) and supported by the "Reference Values for Nutrient Intake" of the German Nutrition Society (2002). Secondly, there are the considerations of the US Food and Drug Administration; FDA (2006) when discussing a qualified health claim for rapeseed oil as vegetable oil. These arguments refer to the original (erucic acid free) variety of rapeseed oil containing around 10\% linolenic acid. This vegetable oil quality is referred to as "canola" in North America (Barth 2009). In the following some nutritional considerations are pinpointed comparing newly introduced high oleic/low linolenic acid (so-called HOLLi) varieties with the original variety containing around $10 \%$ linolenic acid (Table 1). The term "rapeseed oil" is used for the original (erucic acid free) variety with around 10\% linolenic acid (Barth 2009; The Paleo Diet 2015). Recently, researches are being conducted to develop rapeseed lines with higher amount of Lauric and myristic acid for direct use of rapeseed oil as margarine following transformation and antisense techniques (Möllers 2016; personal communication). These two short chain fatty acids are absence in naturally occurring rapeseed fatty acid de novo biosynthesis pathway (Puyaubert et al. 2005).

In the last decade this genera also gain attention to being not only as the source of edible vegetables and oils but also source of healthy oils, bio-fuel and industrial feed-stock (Möllers 2004; Nath 2008). Therefore, the fatty acid compositions of the rapeseed oils have been modified according to specific objectives through conventional and molecular breeding. Very Long Chain Fatty Acids (VLCFAs) is currently used in cosmetic, polymer and emollient industry for lubricant, adhesive and biodegradable plastics products. The rapeseed oil with more than $60 \%$ erucic acid could be used directly as industrial

Table 1. Fatty acids composition of different rapeseed oil quality type compare with different other crop plants available for food and industrial use (Source: Möllers 2004; Nath 2008; The Paleo Diet 2015).

\begin{tabular}{|c|c|c|c|c|c|c|}
\hline Rapeseed oil type and/crop type & $\begin{array}{c}\text { Fatty acids } \\
<\mathrm{C} 16\end{array}$ & $\begin{array}{c}\text { Saturated } \\
\text { fatty acids }\end{array}$ & $\begin{array}{c}\text { Oleic acid } \\
\text { C18:1 }\end{array}$ & $\begin{array}{c}\text { Linoleic acid } \\
\text { C18:2 }\end{array}$ & $\begin{array}{c}\text { Linolenic } \\
\text { acid C18:3 }\end{array}$ & $\begin{array}{c}\text { Erucic acid } \\
\text { C22:1 }\end{array}$ \\
\hline \multicolumn{7}{|l|}{ Rapeseed } \\
\hline ‘00’ Canola & $<1$ & 7 & 60 & 20 & 10 & $<2$ \\
\hline High Erucic (HEAR) & $<1$ & 2 & 13 & 3 & 3 & $78^{\mathrm{y})}$ \\
\hline Low-Linolenic (LLi) & $<1$ & 7 & 60 & 30 & $<2$ & $<2$ \\
\hline High Oleic (HOAR) & $<1$ & 5 & 86 & 4 & 4 & $<2$ \\
\hline High Oleic/Low-Linolenic (HOLLi) & $<1$ & 5 & 85 & 6 & 2 & $<2$ \\
\hline Palm & $<1$ & 48 & 37 & 9 & $<1$ & $<2$ \\
\hline Soybean & $<1$ & 14 & 24 & 52 & 7 & $<2$ \\
\hline Cotton & $<1$ & 25 & 18 & 52 & $<1$ & $<2$ \\
\hline Sunflower & $<1$ & 11 & 20 & 66 & $<1$ & $<2$ \\
\hline HO sunflower line ${ }^{x}$ & $<1$ & 6 & 90 & 3 & 0 & $<1$ \\
\hline
\end{tabular}

\footnotetext{
${ }^{2)}$ Mainly Palmitic acid (C16:0) and stearic acid (C18:0).

${ }^{\mathrm{y})}$ Included $\sim 6 \%$ Eicosenoic acid (C20:1).

${ }^{\mathrm{x})}$ HO-High Oleic.
} 
feedstock without any fractional distillation (Piazza and Foglia 2001). Thus, researches (renewable energy sources, RES) have gained much support in policy level and research grants to increase the share of RES in energy sectors have been adopted.

The EU target is to increase its RES from 5.4\% in 1997 to $40.0 \%$ by 2020 (Rosillo-Calle 2006). Recently, Biodiesel among other RES is highly being promoted. This is because the resources are abundant, can be generated in a short period of time and obtained from different sources (waste products, forest and crops). Biodiesel production would provide employment opportunities through the cultivation, harvesting, transporting and conversion to bioenergy (Rosillo-Calle 2006). Also, it can be used to generate different forms of energy including heat, electricity and fuel. In $2000,79.8 \%$ out of $13.8 \%$ of RES used worldwide was from biomass (IEA 2002) and in Europe, $66.1 \%$ of RES used was biomass and biodiesel (EC 2006; Ofori 2008). Therefore, this review concentrated on the potentiality of rapeseed oil as source of healthy vegetable oil and alternate renewable energy or industrial feedstock.

\section{MAIN SUBJECT}

\section{Importance of rapeseed}

Rapeseed is an important source of vegetable oil and regarding world oilseed production it is now the second largest oilseed crop after soybean (FAO 2014). Rapeseed has gained acceptance worldwide largely because of major improvements in the seed oil and meal quality. World vegetable oil markets are highly competitive requiring a steady improvement in oil quality to increase market prospects. The objective of modifying oil quality is to develop oils with enhanced nutritional and functional properties and which require if possible no further processing for specific end-use markets. The market of rapeseed oil is primarily for human consumption, but also for a range of industrial applications (Craig and Millam 1995). Presently, different types of rapeseeds with a modified fatty acid composition are available for different purposes. With a worldwide production of 65 million tonnes of rapeseed was produced in 2013, it ranks behind only soybeans in world oilseed crop production. Rapeseed/Canola is grown principally as a source of edible oil; however it is being used more frequently in the production of biodiesel, especially in the EU where almost ten million tonnes of biodiesel were produced in 2013, mainly from canola oil (EBB 2014).

\section{Modification of fatty acid composition of rapeseed oil}

Most of the rapeseed oil is produced for human consumption in the form of margarine, fried and backed products and salad oil. Several attempts have been made through conventional breeding and transgenic approaches for modifying the fatty acid compositions to make the rapeseed oil more suitable for specific food and non-food utilization (Möllers 2004). Among the different approaches, development of high oleic acid rapeseed (HOAR) oil is important for both food and non-food purposes. Previously, this oil was used only for human consumption as salad oil or partially hydrogenated for frying and deep-frying purposes. However, studies published by Käb (2001); Piazza and Foglia (2001) summarized impressively the various application of HOAR. Those findings brought hope of the ever increasing market of HOAR at the present state (von Borcke 2014). Modifications of the fatty acids composition in rapeseed have been achieved beyond the natural occurring variation by mutation breeding and genetic engineering. As the EU do not accept the transgenic crop, therefore the utilization of mutation breeding cultivars with high oleic (HO) acid content has currently better chances being realized (Ayton 2014).

\section{Development of high oleic acid oilseed rape (HOAR)}

$\mathrm{HO}$ acid vegetable oil is being popular as source of stable and healthy fried oil. Therefore, HO-sunflower, HO-soybean and HO-safflower cultivars have taken lead in vegetable market in Europe, Australia and North America. In rapeseed breeding, efforts have made for many years focusing on increasing the oleic acid content. In Germany, mutation experiments were started about 20 years ago and first mutant with $\mathrm{HO}$ acid content was selected by Rücker and Röbbelen (1996). Genetic studies confirmed that the selected mutant line was inherited by single gene in an 
additive manner (Schierholt et al. 2001). In a doubled haploid population segregating for oleic acid revealed that mutation itself increased of $11 \%$ oleic acid from $60 \%$ to $71 \%$ compared to wild type (Schierholt 2001). Molecular mapping of the mutated genes confer that oleic acid desaturase gene (FAD2; $\triangle-12$ oleate desaturase) being mutated (Fig. 1). FAD2 gene catalyses the introduction of the second carbon bond into oleic acid and thereby producing polyunsaturated fatty acids (Slabas et al 2001; von Borcke 2014). Previously, it was assumed that there are two $F A D 2$ alleles present in $B$. napus; one from $B$. oleracea and other from $B$. rapa brought change the oleic acid content in the oil of B. napus (Möllers 2004).

Now Ian Bancroft and Rachel Wells at the John Innes

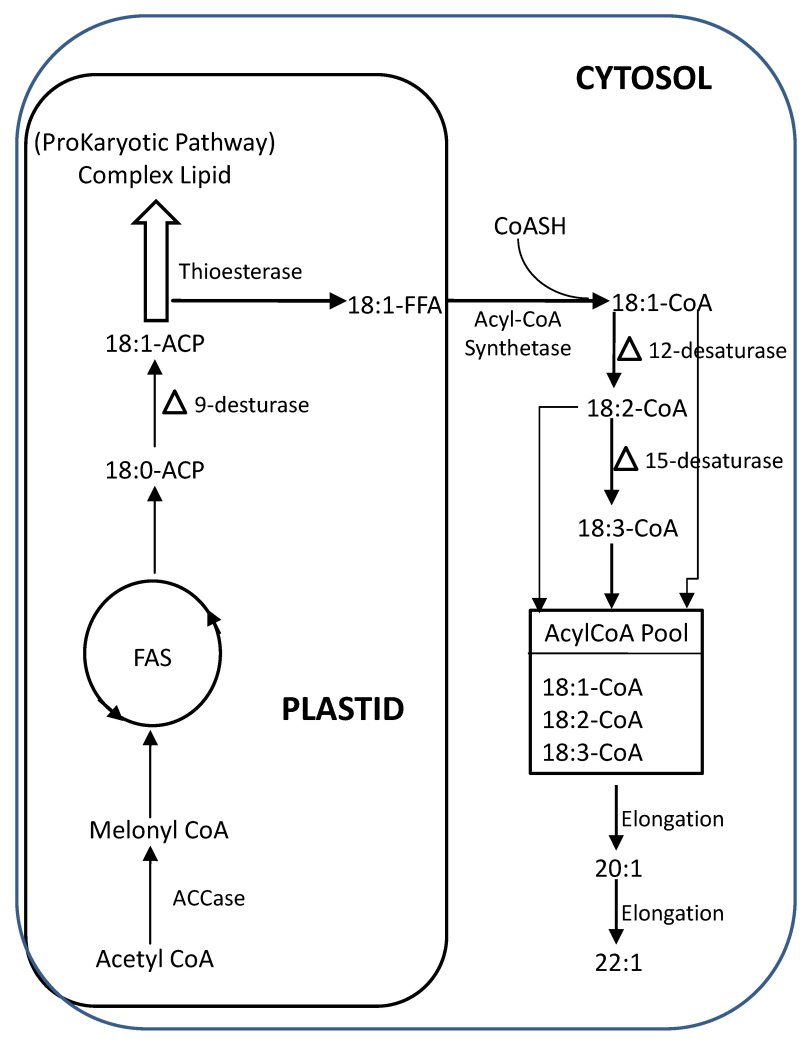

Fig. 1. Cellular and molecular mechanism of biosynthesis of fatty acids in Brassica napus utilising ACP substrates in the plastid and subsequent reactions on CoA substrates occuring in the cytoplasm (adapted from Slabas et al. 2001; Nath 2008). ACCase: acetyl-CoA carboxylase, ACP: acyl carrier protein, FAS: fatty acid synthetase, CoASH: activated CoA.
Centre (JIC), Canada have been able to increase the oleic acid content in rapeseed oil significantly beyond the level of current varieties. Their work has confirmed the precise number of alleles of the FAD2 gene found in B. napus. Through detailed genetic studies and sequencing they have found that there are four alleles of the FAD2 gene present in oilseed rape. Combined with their insights into the properties of each individual FAD2 allele they have been able to manipulate the optimal combination of FAD2 alleles in order to obtain new oil-seed rape lines with oleic acid contents of up to $86 \%$ (von Borcke 2014). The JIC team used Ethyl-Methyl Sulphonate mutagenesis to gain oleic acid profile over $86 \%$ and poly-unsaturated fatty acid content below 5\% compared with $\mathrm{HO}$ acid sunflower oil (Table 1).

\section{Development of VLCFA rapeseed lines}

The fatty acids of eicosenoic (C20:1) and erucic acid (C22:1) are considered as VLCFA in rapeseed oil. The occurrence of erucic acid is considered as anti-nutritional factor for human consumption. Therefore, it was minimized by breeding and finally developed Canola- or '00'-quality (Lühs and Friedt 1994; Przybylski and Mag 2002). High Erucic Acid Rapeseed (HEAR) cultivars are regained interest for industrial purposes. Erucic acid (cis-13-docosenoic acid, 22:1) a VLCFA having 22 carbon atoms with one double bond at the cis-13 position of the carbon chain. Genetic studies show that in rapeseed, which arose from a spontaneous cross between $B$. rapa (A-genome) and B. oleracea (C-genome); 22:1 content is controlled by the two gene loci, E1 (Bn-fae1.1; A-genome) and $E 2$ (Bn-fae 1.2; C-genome), which have additive effects (Harvey and Downey 1964; Stefansson 1983; Lühs et al. 1999; Nath et al. 2009b). Studies of Arabidopsis thaliana mutants deficient in VLCFAs showed that the fatty acid elongase ( $f a e 1)$ gene product is required in the seeds for the elongation from 18:1 to 22:1 (Fig. 1) (Kunst et al. 1992; James et al. 1995; Nath 2008). The development of seed oils bearing a high percentage of erucic acid for industrial applications is a subject of research (Taylor et al. 1995; Kott et al. 1996) because it is a very excellent renewable raw material used in plastic film manufacture, in the synthesis of nylon and in the lubricant and emollient 
industries (Leonard 1994; Sonntag 1995; Murphy 1996). A rapeseed line containing high proportions of erucic acid would significantly reduce the processing costs of itself for using as the industrial feed-stock.

Genetic (Kunst et al. 1992) and biochemical (Cassagne et al. 1994; Domergue et al. 1998) studies have suggested the existence of several elongase activities in Brassica. In the presence of labeled malonyl-CoA, VLCFAs could be synthesized from acyl-CoAs (acyl-CoA elongation) of the microsomal lipids; there is an absolute requirement for adenosine triphosphate (ATP) (ATP dependent elongation; Domergue et al. 1999). In the case of acyl-CoA elongation, Lessire et al. (1985) demonstrated that successive additions of C2 units to stearoyl-CoA (18:0-CoA) were responsible for the sequential synthesis of arachidonoyl-CoA (20:0-CoA), behenoyl2. CoA (22:0-CoA) and lignoceroylCoA (24:0-CoA). Several studies suggested that two biochemical steps are critical for improvement of erucic acid production in rapeseed: membrane bound fatty-acid elongation and lysophosphatidic acid acyltransferase (LPAAT) activity leading to the biosynthesis of trierucin. The gene of an erucoyl-CoA preferring acyltransferase (Ld-LPAAT) has been successfully cloned from meadow- foam (Limnanthes douglasii L.) and over expressed in rapeseed (Brown et al. 1995; Hanke et al. 1995; Lassner et al. 1995; Brough et al. 1996; Han et al. 2001). However, the overall proportions of 22:1 in the seed oil did not increase. However, the $L d-L P A A T$ transgene approach were successful in achieving high trierucin content in HEAR B. napus seed oil. Weier et al. (1997) suggested that the level of trierucin depends not only on the activity of the introduced sn-2-acyltransferase but also on other biosynthesis or incorporation steps. It is possible that the levels of erucoyl-CoA in the seed acyl-CoA pool may be too low to allow high levels of trierucin biosynthesis. If this is the case, then over-expression of genes regulating VLCFAs biosynthesis may be required to boost very long-chain acyl-CoA availability for incorporation into seed triacylglycerols (TAGs).

Attempts are being made by conventional breeding to increase the erucic acid content. This has so far resulted in breeding lines with up to $60 \%$ erucic and eicosenoic acid. These fatty acids are found in the $s n-1$ and the $s n-3$ position of the TAGs but are excluded from the $s n-2$ position (Fig. 2B). This $s n-2$ exclusion limits the erucic acid content theoretically to total of $66 \%$ (33\% in each of the $s n-1$ and

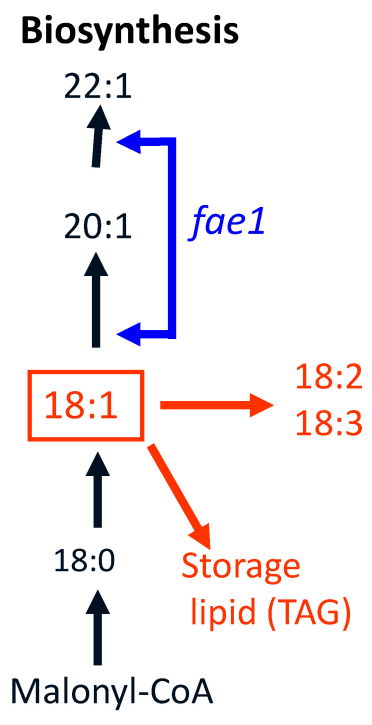

A.

\section{Limitations}

1. Efficiency of the fatty acid elongase (fae1) gene; KCS=ß-ketoacyl-CoA synthase

2. Esterfication of 22:1 at sn-2 position in triacylglyceride (TAG)

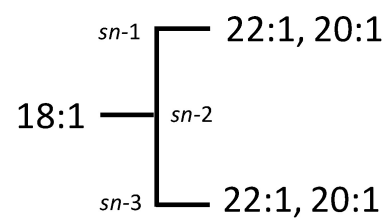

3. Availability of 18:1-CoA for elongation

B.

Fig. 2. Schematic diagram of biosynthetic pathway of erucic acid in developing seeds of rapeseed of 2 steps elongation starting from 18:1-CoA pool (A) and probable 3 limiting factors for elongation of fatty acids from 18:1-CoA to 22:1 (B). 
$s n-2$ position) and prevents the synthesis of trierucin (Cao et al. 1990; Frentzen 1993; Katavic et al. 2001; Nath et al. 2009a). The gene of an erucoyl-CoA preferring $s n-2$ acyltransferase from Limnanthes douglasii (Ld-LPAAT) has been successfully cloned and over expressed in rapeseed (Brown et al. 1995; Hanke et al. 1995; Lassner et al. 1995; Brough et al. 1996; Friedt and Lühs 1998; Han et al. 2001). However, the overall proportions of 22:1 in the seed oil did not increase (Han et al. 2001). In a next step, interest focused on the fatty acid elongation mechanism from oleic acid to eicosenoic acid and then to erucic acid (Fig. 2A). This elongation is the result of two cycles of a four-step mechanism, in which 18:1-CoA and 20:1-CoA are used as substrates. The first step, the initial condensation reaction of these fatty acids with malonyl-CoA is catalysed by the $\beta$-ketoacyl-CoA synthase (KCS; Fig. 1). It is believed that this initial reaction is the rate-limiting step (Cassagne et al. 1994). The fae 1 gene encoding the KCS, has been cloned from a range of plant species and has been over expressed under control of a seed specific promoter in HEAR. However, only very minor increases in 22:1 content were reported (Han et al. 2001; Katavic et al. 2001). Even in combination with the $L d-L P A A T$ no substantial increase in 22:1 content has been found (Han et al. 2001). It seems that there are other bottlenecks in the pathway, such as the pool of oleic acid available for elongation to eicosenoic and erucic acid (Fig. 2B). To study the question if availability of 18:1-CoA is limiting for 22:1 synthesis, Sasongko and Möllers (2005) crossed HEAR (cv. Maplus) to HOAR (Schierholt et al. 2001) to recombine the genes for high 22:1 with those for high 18:1 (i.e., low content of polyunsaturated fatty acids). However, the recombinant line High Erucic and Low Polyunsaturated fatty acid (HELP) did not show a significant change of 22:1 acid content, indicating that in this material the $\beta$-ketoacyl-CoA synthase activity may be limiting (Fig. 2B). To test this hypothesis, two separate approaches were followed involving two transgenic lines over expressing the fae 1 gene in combination with the $L d-L P A A T$ gene. Those lines were crossed to the line 6575-1 HELP. Segregating populations were studied for the inheritance of erucic acid content and other traits (Nath et al. 2009a; 2009b). From their study, they have been reported first to develop high erucic acid rapeseed lines with more than 78\% VLCFA including 6\% eicosenoic acid in the seed oil. Those lines are now available for the researchers and growers, to whom are interested for HEAR, in the plant breeding department, Georg-August University, Germany.

\section{B. napus as medicinal food plant}

The rapeseed oil is usually used for medicinal or food purposes. In Iranian traditional medicine, the root parts of Colza were used for the therapeutic purposes as diuretic, anti-scurvy, anti-inflammatory of bladder and anti-cold (Zargari 2001). The seeds are also used for treatment of hepatic and kidney disease. Rapeseeds are also used in the Eastern folk medicine as bronchial cathartic (Evans 1997; Zargari 2001). It has been reported that rapeseed oil diet contained $326 \mathrm{mg}$ more plant sterols than the olive oil diet. Rapeseed oil decreases cholesterol absorption by $11 \%$, and increased excretion of cholesterol, bile acids, and their sum as sterols by 9,32 , and $51 \%$ compared to olive oil. The serum cholesterol level could be decreased by $7 \%$ (Ellegård et al. 2005).

Saeidnia and Gohari (2012) reported that intake a diet with $10 \%$ rapeseed oil for 13 weeks increased systolic blood pressure, plasma levels of $\mathrm{Na}+$ and lipids, and decreased the level of $\mathrm{K}+$ compared to those in the soybean oil group. They suggested that an increase in body fluid via activation of $\mathrm{Na}+$ pump or $\mathrm{Na}+, \mathrm{K}+-\mathrm{ATPase}$ and/or a blunt endothelium-dependent vasodilation by increased superoxide might be related to increase of blood pressure and hence, these would promote the peripheral vascular lesions and atherosclerotic vascular injury (Naito et al. 2000). Presently, rapeseed oil has also been used as component of bio-pesticides against fungi. The antifungal activity have been confirmed by linolenic, linoleic and oleic acids against plant pathogenic fungi; Rhizoctonia solani, Pythium ultimum, Pyrenophora avenae and Crinipellis perniciosa (Walters et al. 2004).

\section{Rapeseed oil as biodiesel}

Fossil fuels from coal, natural gas and petroleum (oil) have been the main sources of energy since the mid 1800s. In 2005 , fossil energy is contributed about $79 \%$ of the total energy consumption in the EU countries and $81 \%$ 
worldwide (EC 2007). However, there is large global threatened of shortage of fossil fuel due to continuous mining of this resources. Therefore, it is necessary to develop technology and alternative plants for renewable and green energy as well as ensure security in the ever expending energy sector for our upcoming generations. The mining, processing, and combustion of fossil fuels also produce $\mathrm{CO}_{2}$ and other gases which are contributing significantly to increase in concentration of atmospheric $\mathrm{CO}_{2}$ and finally greenhouse effect (Houghton 2001). The first global attempt to search for solutions to these problems was the Kyoto protocol was introduced in 1997 by the United Nations. Thereafter, RES of bio-, water-, wind- and solar-energy is being promoted because they are neutral to the production of $\mathrm{CO}_{2}$ and replaceable.

Biodiesel is a fuel defined as methyl esters (FAME) of long-chain fatty acids derived from renewable biological sources. Compatibility of biodiesel with mineral oils allows combining them in order to obtain a stable fuel mixture (Dworakowska et al. 2011). It can be used in the form of pure methyl esters of fatty acids as well as mixed with diesel fuel containing up to $30 \%$ of biological oil (Knothe et al. 1997; Fukuda et al. 2001; Tyson et al. 2004; Leung et al. 2010). Biofuels production has been raised rapidly in the last twenty years. Growing tendency can be expected in the future, if national governments of different countries continue in achievement of higher share of 'green energy'. Diversification and self-sufficiency in energy and environmental aspects should underpin national and international policy. Consumption of biofuels in the transport sector has been significantly increasing since 2000. Biofuels produced in the EU are mostly first-generation biofuels, mainly produced from agricultural raw materials. Vegetable oils belong to the renewable materials that are currently used also for the production of biodiesel. Production of biodiesel by trans-esterification of vegetable oils is currently the primary source of biodiesel. The most widely used input material for biodiesel production in the $\mathrm{EU}$ is rapeseed oil made from rapeseed, which accounts for the production of biodiesel in the range of $57 \%$ to $70 \%$ (Zentková and Cvengrošová 2013). Therefore, HEAR oil bring an idea to use as biodiesel for their characteristic properties with very high number of carbon atoms (C22:1) and potentiality to produce more energy.

Serra et al. (2010) reported that rapeseed has become more 'independent' and gradually has been changing into a crop with significant industrial use (biodiesel). This claim is consistent with the results achieved in the paper. Change in the use of rapeseed has been occurred since 2003. In the year 2003, the EU Biofuels Directive (2003/30/EC) implemented and set targets for biofuels. Shares of rapeseed production for industrial purposes on the total rapeseed production until 2003 ranged from $15 \%$ to $40 \%$. The rest of produced rapeseed was used for its primary purpose, which is food and feed processing.

In the EU, $77 \%$ of biodiesel production is produced from rapeseed oil (Fig. 3). Other plants oil involved in the production of biodiesel are soybean oil and palm oil, which are mostly imported into Europe. The shares of soybean oil and palm oil in the production of biodiesel in the EU are 9\% and $12 \%$, respectively. The rest of the production of biodiesel coming from waste materials is estimated to make 2\% (USDA 2011). Zentková and Cvengrošová (2013) reported that the ever increasing demand of biodiesel leads to an increase in production and acreage of rapeseed as an input for biodiesel production. Production of biodiesel represents new opportunities for farmers for the placement of their production. The growth of biodiesel production also leads to changes in orientation of rapeseed consumption and utilization.

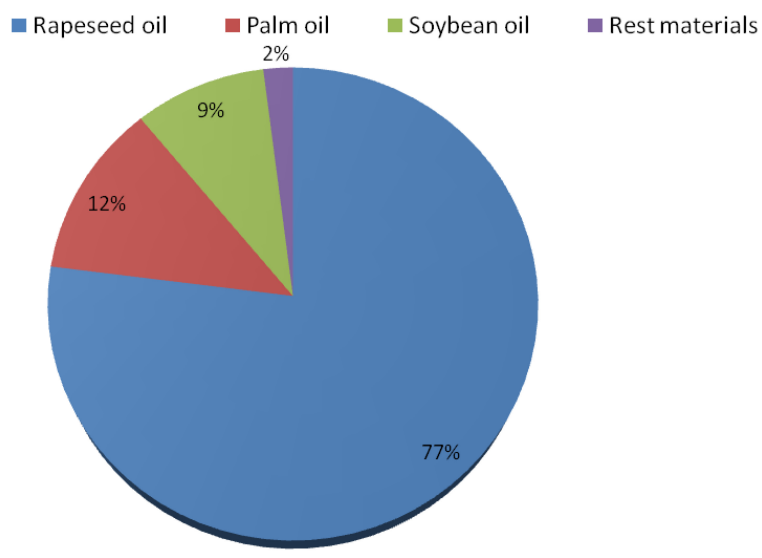

Fig. 3. Different kinds of plant oil used directly as biodiesel in the year 2010 in the EU. Source: USDA 2011, adopted from Zentková and Cvengrošová (2013). 


\section{CONCLUSIONS AND FUTURE OUTLOOK}

Rapeseed oil plays a vital role in the world vegetable oil market. Fatty acids composition has been modified as per the end-user demand. However, to offer the best choice of healthy and acceptable food to the consumer a coordination of plant breeding, food processing and nutrition science is required. Here, the nutritional aspects of modified fatty acid rapeseed oil have not reviewed in detail. Although the use of HOLLi oil in consumption by the consumer should have high priority from the standpoint of public health. To pursue this aim confusion of the consumer must be avoided by creating a new name and a new brand for HOLLi varieties. However, there is vast scope in future outlook for modifying the fatty acid composition of rapeseed oil. It is possible to produce rapeseed oil with satisfactory amount of lauric acid and myrestic acid for using as vegetable margarine through over-expression of genes from coconut.
Furthermore, during oilseed development, significant amounts of sugar provided by photosynthesis are converted to storage TAGs by the developing seed in rapeseed. In oilseed plants, at which the pathway commits the fixed carbon to lipid biosynthesis is the conversion of acetyl-CoA. The temporal distribution of ATP-citrate lyase (ACL) activity in developing seeds of rapeseed closely paralleled both that of acetyl-CoA carboxylase (ACCase) in the cytosol and the overall rate of lipid biosynthesis (Fig. 4; Fatland et al. 2005). Therefore, over-expression of ACL gene will help to produce more acetyl-CoA in the cytosol from mitochondria, which might have possibility to produce necessary malonyl-CoA for long chain fatty acid biosynthesis. In combination with transgenic and mutation to stop competition of acetyl-CoA pool for synthesis of plant secondary metabolites (Fig. 4) could bring further breakthrough in develop higher amount of long chain fatty acid rapeseed genotypes beyond the current level.

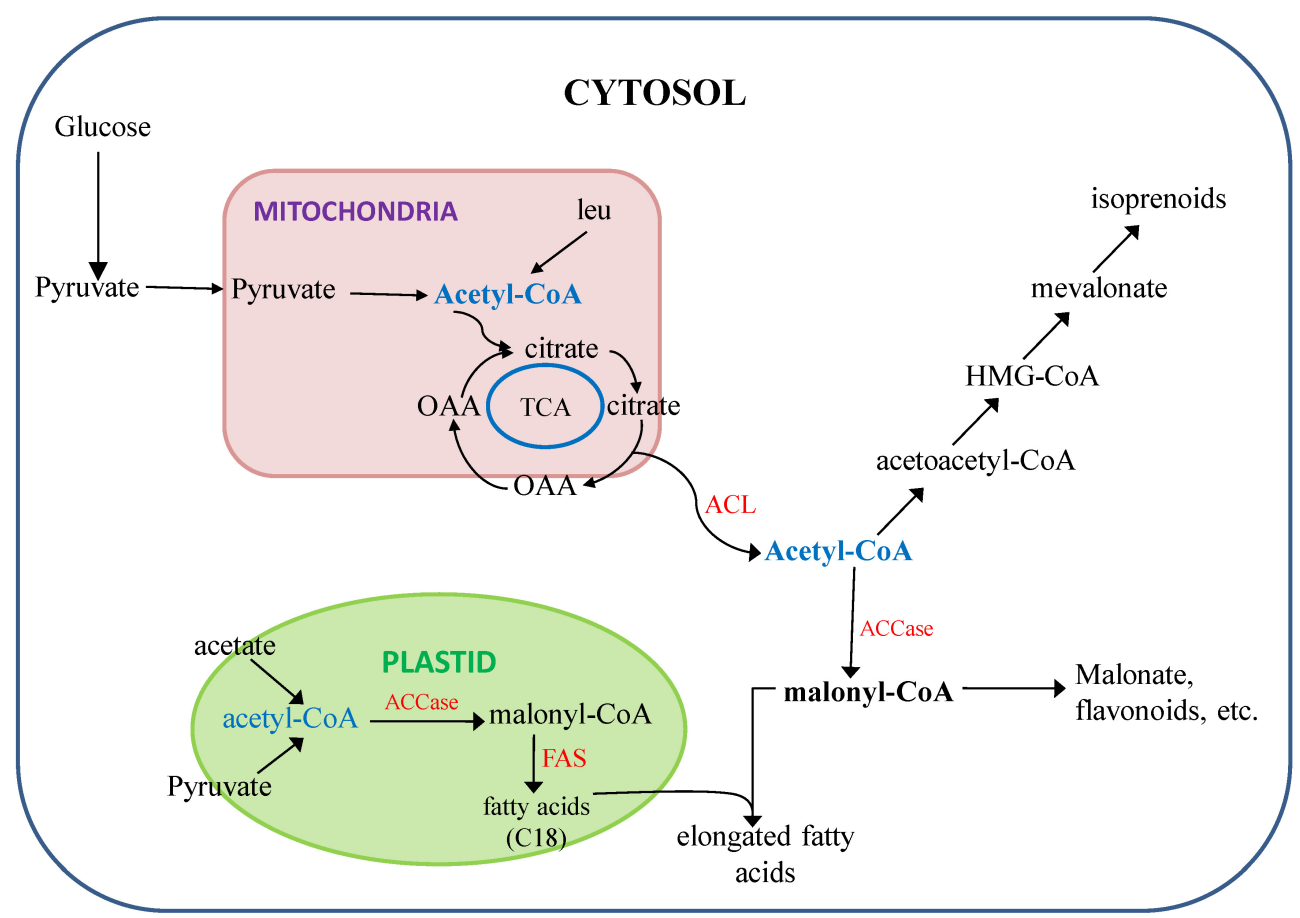

Fig. 4. Scheme of putative fatty acids and different metabolites (isoprenoids, malonate, flavonoids, etc.) biosynthetic pathways in plants (following Fatland et al. 2005; Nath 2008). ACL is depicted together with a postulated citrate cycle that would provide citrate from the mitochondria. In the cytosol, acetyl-CoA can be carboxylated by ACCase to form malonyl-CoA and hence converted to long chain fatty acids (22:1).

FAS: fatty acid synthase, TCA: tricarboxylic acid cycle, leu: leucine, ACL: ATP-citrate lyase, ACC: acetyl-CoA carboxylase. 


\section{ACKNOWLEDGEMENTS}

This research was supported by the Golden Seed Project (No. 213003-04-4-SB110) of the Ministry of Agriculture, Food and Rural Affairs (MAFRA) of the Republic of Korea.

\section{REFERENCES}

Ayton J. 2014. Variability of quality traits in canola seed, oil and meal-a review. New South Wales Department of Primary Industries, New South Wales, Australia.

Barth CA. 2009. Nutritional value of rapeseed oil and its high oleic/low linolenic variety-A call for differentiation Eur. J. Lipid Sci. 111: 953-956.

Brough CL, Coventry JM, Christie WW, Kroon JTM, Brown AR, Barsby TL, et al. 1996. Towards thegenetic engineering of triacylglycerols of defined fatty acid composition: major changes in erucic acid content at the $s n-2$ position affected by the introduction of a 1-acyl-snglycerol-3-phosphate acyltransferase from Limnanthes douglasii into oilseed rape. Mol. Breed. 2: 133-142.

Brown AP, Brough CL, Kroon JT, Slabas AR. 1995. Identification of a cDNA that encodes a 1-acyl-sn-glycerol3-phosphate acyltransferase from Limnanthes douglasii. Plant Mol. Biol. 29: 267-278.

Cao YZ, Oo KC, Huang AH. 1990. Lysophosphatidate acyltransferase in the microsomes from maturing seeds of meadowfoam (Limnanthes alba). Plant Physiol. 94: 1199-1206.

Cassagne C, Lessire R, Bessoule JJ, Moreau P, Creach A, Schneider F, et al. 1994. Biosynthesis of very long chain fatty acids in higher plants. Prog. Lipid Res. 33: 55-69.

Craig A, Millam S. 1995. Modification of oilseed rape to produce oils for industrial use by means of applied tissue culture methodology. Euphytica 85: 323-327.

Domergue F, Bessoule JJ, Moreau P, Lessire R, Cassagne C. 1998. Recent advances in plant fatty acid elongation, p.185-222. In: J. L. Harwood (ed.). Fundamental and agricultural applications. Cambridge University Press, Cambridge, UK.

Domergue F, Chevalier S, Santarelli X, Cassagne C, Lessire R. 1999. Evidence that oleoyl-CoA and ATP-dependent elongations coexist in rapeseed (Brassica napus L.). Eur.
J. Biochem. 263: 464-470.

Dworakowska S, Bednarz S, Bogdal D. 2011. Production of biodiesel from rapeseed oil. Proc. of the 1st World Sustainability Forum. Online (Available from: www. wsforum.org).

EBB. 2014. European Biodiesel Board [Internet]. European Biodiesel Board, Brussels, Belgium. [cited 2016 May 16]. Available from: http://www.ebb-eu.org/stats.php.

EC. 2006. Energy for the future: renewable sources of energy, European Commission report [Internet]. European Commission, Brussels, Belgium. [cited 2016 May 16]. Available from: http://ec.europa.eu/energy/res/sector/ bioenergy_en.htm.

EC. 2007. Energy and transport in figures. Statistical pocket book, European Commission, energy and transport [Internet]. European Commission, Brussels, Belgium. [cited 2016 May 16]. Available from: http://ec.europa.eu/dgs/energy_transport.

Ellegård L, Andersson H, Bosaeus I. 2005. Rapeseed oil, olive oil, plant sterols, and cholesterol metabolism: an ileostomy study. Eur. J. Clin. Nutr. 59: 1374-1378.

Evans WC. 1997. Trease and Evans' pharmacognosy. 14th ed. WB Saunders Company Ltd., London, UK.

FAO. 2014. Agricultural data. FAOSTAT [Internet]. Food and Agriculture Organization of the United Nations, Rome, Italy. [cited 2016 May 13]. Available from: http://www.fao.org/economic/ess/ess-publications/ess-y earbook/en.

Fatland BL, Nikolau BJ, Wurtele ES. 2005. Reverse genetic characterization of cytosolic acetyl-CoA generation by ATP-citrate lyase in Arabidopsis. Plant Cell. 17: 182-203.

FDA. 2006. Qualified Health claims: letter of enforcement discretion-unsaturated fatty acids from canola oil and reduced risk of coronary heart disease [Internet]. Food and Drug Administration, Silver Spring, MD. [cited 2006 Oct 6]. Available from: http://wwwcfsanfdagov/,dms/qhccanolhtml.

Frentzen M. 1993. Acyltransferases and triacylglycerols, p.195-220. In: T. S. Moore (ed.). Lipid metabolism in plants. CRC Press, Boca Raton, FL.

Friedt W, Lühs W. 1998. Recent development and perspectives of industrial rapeseed breeding. Eur. J. Lipid Sci. Technol. 100: 219-226.

Fukuda H, Kondo A, Noda H. 2001. Biodiesel fuel production by transesterification of oils. J. Biosci. Bioeng. 92: 405-416. 
German Nutrition Society. 2002. Deutsche gesellschaft für ernährung: reference values for Nutrient Intake. Umschau Braus, Frankfurt, Germany.

Gómez-Campo C. 1980. Studies on Cruciferae: VI. geographical distribution and conservation status of Boleum Desv. Guiraoa Coss. and Euzomodendron Coss. Anal. Inst. Bot. Cavanilles 35: 165-176.

Han J, Lühs W, Sonntag K, Zähringer U, Borchardt DS, Wolter FP, et al. 2001. Functional characterization of beta-ketoacyl-CoA synthase genes from Brassica napus L. Plant Mol. Biol. 46: 229-239.

Hanke C, Wolter FP, Coleman J, Peterek G, Frentzen M. 1995. A plant acyltransferase involved in triacylglycerol biosynthesis complements an Escherichia coli sn-1acylglycerol-3-phosphate acyltransferase mutant. Eur. J. Biochem. 232: 806-810.

Harvey BL, Downey RK. 1964. The inheritance of erucic acid content in rapeseed (Brassica napus). Can. J. Plant Sci. 44: 104-111.

Houghton JT, Ding Y, Griggs DJ, Noguer M, van der Linden PJ, Dai X, et al.; IPCC. 2001. Climate change 2001: the scientific basis. Cambridge University Press, Cambridge, UK.

IEAIEA. 2002. Total energy consumption and biomass share. World Energy Outlook. International Energy Agency, Paris, France.

James DW Jr, Lim E, Keller J, Plooy I, Ralston E, Dooner HK. 1995. Directed tagging of the Arabidopsis FATTY ACID ELONGATION1 (FAE1) gene with the maize transposon activator. Plant Cell 7: 309-319.

Käb H. 2001. Marktanalyse: Industrielle Einsatzmöglichkeiten von High Oleic Pflanzenölen. Fachagentur Nachwachsende Rohstoffe, Gülzow, Germany.

Katavic V, Friesen W, Barton DL, Gossen KK, Giblin EM, Luciw T, et al. 2001. Improving erucic acid content in rapeseed through biotechnology: What can the Arabidopsis FAE1 and the yeast SLC1-1 genes contribute? Crop Sci. 41: 739-747.

Kimber D, McGregor DI. 1995. Brassica oilseeds-production and utilization. $\mathrm{CAB}$ International, Wallingford, UK. p.394.

Knothe G, Dunn RO, Bagby MO. 1997. Biodiesel: the use of vegetable oils and their derivatives as alternative diesel fuels, p.172-208. In: B. C. Saha, J. Woodward (ed.). Fuels and chemicals from biomass. ACS Symposium Series
666. American Chemical Society, Washington, DC.

Kott L, Wong R, Swanson E, Chen J. 1996. Mutation and selection for improved oil and meal quality in Brassica napus utilizing microspore culture, p.151-167. In: S. M. Jain, S. K. Sopory, R. Veilleux (ed.). In vitro haploid production in higher plants. Kluwer Academic Publ., Dordrecht, Netherlands.

Kunst L, Taylor DC, Underhill EW. 1992. Fatty acid elongation in developing seeds of Arabidopsis thaliana. Plant Physiol. Biochem. 30: 425-434.

Lassner MW, Levering CK, Davies HM, Knutzon DS. 1995. Lysophosphatidic acid acyltransferase from meadowfoam mediates insertion of erucic acid at the $s n-2$ position of triacylglycerol in transgenic rapeseed oil. Plant Physiol. 109: 1389-1394.

Leonard C. 1994. Sources and commercial applications of high erucic vegetable oils. Lipid Technol. 4: 79-83.

Lessire R, Juguelin H, Moreau P, Cassagne C. 1985. Elongation of acyl-CoAs by microsomes from etiolated leek seedlings. Phytochemistry 24: 1187-1192.

Leung DYC, Wu X, Leung MKH. 2010. A review on biodiesel production using catalyzed transesterification. Appl. Energy 87: 1083-1095.

Lühs W, Friedt W. 1994. The major oil crops, p.5-71. In: D. J. Murphy (ed.). Designer oil crops: breeding, processing and biotechnology. VCH Verlagsgesellschaft Weinheim, New York, NY.

Lühs WW, Voss A, Han J, Gräfin zu Münster A, Weier D, Wolter FP, et al. 1999. Genetic modification of erucic acid biosynthesis in Brassica napus, p.323-330. In: G. T. Scarascia Mugnozza, E. Porceddu, M. A. Pagnotta (ed.). Genetics and breeding for crop quality and resistance. Developments in Plant Breeding Vol. 8. Kluwer Academic Publishers, Dordrecht, Netherlands.

Möllers C. 2004. Development of high oleic acid oilseed rape. Proc. of the Vortrag auf dem 8. Internationalen Fachkongress für Nachwachsende Rohstoffe und Pflanzenbiotecnologie NAROSSA, 2002, Magdeburg, Germany.

Möllers C. 2016. Personal communication. Department of Crop Science, division-Plant Breeding. Georg-August University, Göttingen.

Murphy DJ. 1996. Engineering oil production: rapeseed and other oil crops. Trends Biotechnol. 14: 206-213.

Naito Y, Kasama K, Yoshida H, Ohara N. 2000. 
Thirteen-week dietary intake of rapeseed oil or soybean oil as the only dietary fat in Wistar Kyoto rats-change in blood pressure. Food Chem. Toxicol. 38: 811-816.

Nath UK. 2008. Increasing erucic acid content in the seed oil of rapeseed (Brassica napus L.) by combining selection for natural variation and transgenic approaches $[\mathrm{PhD}$ Thesis]. Göttingen, Georg-August University.

Nath UK, Goswami G, Clemens R, Becker HC, Möllers C. 2009a. Inheritance and variation of erucic acid content in a transgenic rapeseed (Brassica napus L.) doubled haploid population. Mol. Breed. 23: 125-138.

Nath UK, Wilmer JA, Wallington EJ, Becker HC, Möllers C. 2009b. Increasing erucic acid content through combination of endogenous low polyunsaturated fatty acids alleles with Ld-LPAAT + Bn-fae 1 transgenes in rapeseed (Brassica napus L.). Theor. Appl. Genet. 118: 765-773.

Ofori A. 2008. Genetic diversity based on SSR markers, heterosis and yield performance of Brassica rapa for biomass production $[\mathrm{PhD}$ Thesis]. Georg-August University, Göttingen.

Piazza GJ, Foglia TA. 2001. Rapeseed oil for oleochemical uses. Eur. J. Lipid Sci. Technol. 103: 405-454.

Przybylski R, Mag T. 2002. Canola/rapeseed oil, p.98-127. In: F. D. Gunstone (ed.). Vegetable oils in food technology composition, properties and uses. Blackwell Publishing, CRC Press, Boca Raton, FL.

Puyaubert J, Garcia C, Chevalier S, Lessire R. 2005. Acyl-CoA elongase, a key enzyme in the development of high-erucic acid rapeseed? Eur. J. Lipid Sci. Technol. 107: 263-267.

Rakow G. 2004. Species origin and economic impotance of Brassica, p.1-7. In: E. C. Pua, C. J. Douglas. Biotechnology in agriculture and forestry. Springer-Verlag, Berlin-Heidelberg, Germany.

Rosillo-Calle F. 2006. Biomass energy: An overview, p.334-737. In: K. Heinloth (ed.). Renewable energy. Springer, Berlin-Heidelberg, Germany.

Rücker B, Röbbelen G. 1996. Impact of low linolenic acid content on seed yield of winter oilseed rape (Brassica napus L.). Plant Breed. 115: 226-230.

Saeidnia S, Gohari AR. 2012. Importance of Brassica napus as a medicinal food plant. J. Med. Plants Res. 6: 2700-2703.

Sasongko ND, Möllers C. 2005. Toward increasing erucic acid content in oilseed rape (Brassica napus L.) through the combination with genes for high oleic acid. J. Am. Oil Chem. Soc. 82: 445-449.

Schierholt AB, Rücker B, Becker HC. 2001. Inheritance of high oleic acid mutations in winter oilseed rape (Brassica napus L.). Crop Sci. 41: 1444-1449.

Serra T, Zilberman D, Gil JM, Goodwin BK. 2010. Price transmission in the US ethanol market, p.55-72. In: M. Khanna, J. Scheffran, D. Zilberman (ed.). Handbook of bioenergy economics and policy. Vol. 33. Springer, New York, NY.

Slabas AR, Simon JW, Brown AP. 2001. Biosynthesis and regulation of fatty acids and triacyglycerides in oil seed rape. Current status and future trends. Eur. J. Lipid Sci. Technol. 103: 455-466.

Sonntag NOV. 1995. Industrial utilization of long-chain fatty acids and their derivatives, p.339-352. In: D. S. Kimber, D. I. McGregor (ed.). Brassica oilseeds. CAB International, Oxon, UK.

Stefansson BR. 1983. The development of improved rapeseed cultivars, p.143-159. In: J. K. G. Kramer, F. D. Sauer, W. J. Pigden (ed.). High and low erucic acid rapeseed oils. Academic Press, Toronto, Canada.

Taylor DC, Barton DL, Giblin EM, MacKenzie SL, Van Den Berg C, McVetty P. 1995. Microsomal lyso-phosphatidic acid acyltransferase from a brassica oleracea cultivar incorporates erucic acid into the $s n-2$ position of seed triacylglycerols. Plant Physiol. 109: 409-420.

The Paleo Diet. 2015. Vegetable oil fatty acid composition [Internet]. The Paleo Diet, Fort Collins, CO. [cited 2016 May 16]. Available from: http://thepaleodiet.com/ vegetable-oil-fatty-acid-composition.

Trautwein EA, Erbersdobler HF. 1998. Rapssorten mit verändertem Fettsäuremuster-eine ernährungswissenschaftliche Betrachtung. UFOP-Schriften "Rapsöl- ein wertvolles Speiseöl". p.27-36.

Tyson KS, Bozell J, Wallace R, Petersen E, Moens L. 2004. Biomass oil analysis: research needs and recommendations. US Department of Energy, Office of Scientific Washington, DC.

USDA. 2011. Oilseeds: World Markets and Trade. United State Department of Agriculture Foreign Agricultural Service, Washington, DC.

von Borcke L. 2014. High oleic acid oilseed: oil seed rape FAD2 mutants with increased mono-unsaturated fatty acid content. Patent Literature, International Publication 
No. WO 2012/117256. US Publication US 2014/0150132

A1. Plant Bioscience Limited, Norfolk, UK.

Walters D, Raynor L, Mitchell A, Walker R, Walker K. 2004. Antifungal activities of four fatty acids against plant pathogenic fungi. Mycopathologia 157: 87-90.

Weier D, Hanke C, Eickelkamp A, Lühs W, Dettendorfer J, Schaffert E, et al. 1997. Trierucoylglycerol biosynthesis in transgenic plants of rapeseed (Brassica napus L.). Eur. J. Lipid Sci. Technol. 99: 160-165.

Zargari A. 2001. Medicinal Plants. 5th ed. Tehran University Publications, Tehran, Iran.

Zentková I, Cvengrošová E. 2013. The utilization of rapeseed for biofuels production in the EU. Visegrad J. Bioecon. Sustain. Dev. 2: 11-14. 